\title{
Preparation and Characterization of Adsorbents for Carbon Dioxide Adsorption
}

\author{
S O. Akpasi and Y M. Isa
}

\begin{abstract}
To reduce emissions of greenhouse gasses, there should be better control of the release of $\mathrm{CO}_{2}$ due to human activities. In this study, an inexpensive material was developed as adsorbents for $\mathrm{CO}_{2}$ capture. Sugarcane bagasse was used as a precursor in preparing activated carbon by chemical activation with zinc chloride $\left(\mathrm{ZnCl}_{2}\right)$ in a laboratory vacuum furnace at $500^{\circ} \mathrm{C}$ for 1 hour while kaolinite was obtained commercially. These adsorbents were applied for the storage of $\mathrm{CO}_{2}$ within a range of temperatures $\left(30^{\circ} \mathrm{C}, 50^{\circ} \mathrm{C}\right.$ and $\left.70^{\circ} \mathrm{C}\right)$ while the flow rate $(30 \mathrm{~mL} / \mathrm{min}$ to $70 \mathrm{~mL} / \mathrm{min})$ and column bed height $(3 \mathrm{~cm}-$ $5 \mathrm{~cm}$ ) were varied at constant temperature. This research also explored sample features such as surface area and porosity, functional groups, and scanning electron microscopic images. This further substantiate the conclusion that $\mathrm{CO}_{2}$ adsorption with kaolinite and activated carbon is favoured at low temperatures, low operating $\mathrm{CO}_{2}$ flowrates and high column bed height.
\end{abstract}

Keywords - sugarcane bagasse, activated carbon, carbonization, chemical activation, adsorption.

\section{INTRODUCTION}

Activated carbon is a porous material with a broad specific surface area that is suitable for the adsorption of gases and aqueous solution solutes. This is attributed to activated carbon properties that have a large active surface area that could provide high capacity for adsorption, well-developed porous structures and strong mechanical properties. [1,2]. Therefore, it has been commonly used for gas separation, solvents recovery, removal of organic pollutants from drinking water and a catalyst support. The need for activated carbon is rising as environmental pollution is becoming a more significant problem. It is a flexible adsorbent due to its excellent adsorption properties. In addition, activated carbon is most frequently used because it is possible to design and modify most of its chemical (e.g. surface groups) and physical properties (e.g. surface area and pore size distribution) according to the appropriate requirement [3]. In addition, because of its simplicity of operation, the adsorption on activated carbon tends to be the most common techniques, because the sorbent material can be produced highly effective, simple to handle and in some cases regenerated. [4].

Manuscript submitted October 19, 2020.

S. O. Akpasi is with the Durban University of Technology, Department of Chemical Engineering, S4 Level 1, Steve Biko Campus, Steve Biko Road, Durban, 4001. SOUTH AFRICA.

Y. M. Isa is with the Department of Chemical Engineering, Durban University of Technology, Steve Biko Campus, Durban, 4001. SOUTH AFRICA.
Activated carbons are produced from a variety of materials from carbonaceous sources. The selection of precursor is based mainly on its availability, cost, and purity, but the production process and specific purpose of the product are also critical factors [5]. Many other agricultural by-products are often used as sources of activated carbon in recent years. Due to their affordability at low costs, widely available, and sustainable resources, agricultural biomass waste has emerged to be promising raw materials for activated carbon production [5]. They have been used to produce activated carbon because of their high carbon content, high adsorption capacity, high density, and substantial good mechanical strength. They also have low ash content, which is suitable within the activated carbon system for constructing highly porous structures. Most agricultural by-products have been found to be ideal precursors for activated carbon due to their high carbon and low ash content, including sugar cane bagasse waste, coconut shell[5, 6], grain sorghum[5], coffee bean husks[5], rubber wood sawdust[5], chestnut wood[5], and fruit stones[5]. In addition, mineral clay is also one of the most available natural materials and is therefore available at a minimal cost. It is possible to substantially extend the use of clays for adsorption and separation. To our best understanding, very few studies have explored kaolinite for $\mathrm{CO}_{2}$ capture so far and studied extensively the parameters relating to its capacity for adsorption. Most research efforts have concentrated on clay minerals from an industrial perspective. Therefore, in this study, sugarcane bagasse was chosen as a precursor to produce activated carbon. In addition, kaolinite was also selected as an adsorbent for $\mathrm{CO}_{2}$ capture via adsorption since both materials are readily available in South Africa (sugarcane bagasse and kaolinite) but have very limited market value.

Due to its excellent natural structure and low ash content, sugarcane bagasse (SCB) is appropriate for the preparation of activated carbons. SCB is a by-product of the sugarcane industry harvested after juice extraction for the manufacture of sugar. The conversion of sugarcane bagasse into activated carbons that can be used as adsorbents, ion exchange, carbon molecular sieve, catalyst will contribute positively to these agricultural products, dramatically alleviate waste disposal costs and provide a fairly inexpensive alternative to conventional commercial carbon products. Carbonization of the precursors at high temperatures in an inert environment supported by the activation phase is the most common technique used for activated carbon preparation. The method of activation is categorized into physical and chemical processes. The Physical activation process comprises treatment of char obtained from carbonization with oxidizing gases, generally 
steam or carbon dioxide at high temperature $\left(400\right.$ to $\left.1000{ }^{\circ} \mathrm{C}\right)$ [7]. In the chemical activation process, the starting material is mixed with an activation reagent and the mixture is heated in an inert atmosphere $[8,9]$. This process is usually done at lower temperature and activation time, higher producing surface area and better porosity as compared to physical activation.

The goal of this study is to prepare activated carbon from sugarcane bagasse by chemical activation using zinc chloride $\left(\mathrm{ZnCl}_{2}\right)$ to adsorb $\mathrm{CO}_{2}$ from its source such as flue gas. To further investigate the adsorption efficiency of activated carbon and kaolinite materials. In this paper, these adsorbents were applied for the storage of $\mathrm{CO}_{2}$ within a range of temperatures $\left(30^{\circ} \mathrm{C}, 50^{\circ} \mathrm{C}\right.$ and $\left.70^{\circ} \mathrm{C}\right)$ while the flow rate $(30 \mathrm{~mL} / \mathrm{min}$ to $70 \mathrm{~mL} / \mathrm{min}$ ) and column bed height $(3 \mathrm{~cm}$ to $5 \mathrm{~cm})$ were varied at constant temperature. Sample characteristics such as the surface area and porosity, functional groups, and scanning electron microscopic images were also investigated in this study.

\section{MATERIAL AND METHODS}

\subsection{Raw material}

The sugarcane bagasse waste (SBW) was selected for activated carbon preparation. SBW was collected from a sugarcane mill company that is located at Kwazulu-Natal in South Africa. The materials were cleaned with distilled water several times to remove dust and impurities while the kaolinite was obtained from South Beach in Durban, South Africa. SBW samples were later dried in the oven at $110^{\circ} \mathrm{C}$ for $24 \mathrm{~h}$ to remove any surface moisture and were then grounded and sieved to particle size range of $150-250 \mu \mathrm{m}$. The proximate analysis of the precursor yielded, moisture $6.4 \%$, volatile matter $31 \%$, fixed carbon $60 \%$ and ash $2.6 \%$.


Fig. 1. (a) Sugarcane bagasse waste (b) Grinded sugarcane bagasse (c) Kaolinite

\subsection{Activation Preparation}

\subsubsection{Chemical activation}

Chemical activation of the powdered precursor was done with $\mathrm{ZnCl}_{2} .10 \mathrm{~g}$ of dried precursor was well mixed with $100 \mathrm{ml}$ solution that contained $10 \mathrm{~g}$ of $\mathrm{ZnCl}_{2}$. The chemical ratio (activating agent/precursor) was $100 \%$ in this case. The mixing was performed at $50{ }^{\circ} \mathrm{C}$ for $1 \mathrm{~h}$. After mixing, the slurry was subjected to vacuum drying at $100{ }^{\circ} \mathrm{C}$ for $24 \mathrm{~h}$. The resulting chemical loaded samples were then transferred into a horizontal kiln furnace as shown in Fig. 3(a). Nitrogen gas flow of 200 $\mathrm{mL} / \mathrm{min}$ was used for making an inert environment inside the reactor and transporting out the volatile compounds. The reactor was heated to $500{ }^{\circ} \mathrm{C}$ and was kept at this temperature for about $1 \mathrm{~h}$ (heating rate of $10{ }^{\circ} \mathrm{C} / \mathrm{min}$ ). The reactor was cooled down after the activation process was completed, and the char was extracted and washed repeatedly with distilled water to about 5 times to eliminate residual $\mathrm{Zn}$, followed by drying at 80 ${ }^{\circ} \mathrm{C}$ till the solution is neutralized to achieve activated carbon. Finally, the product of ACs were ground to a fine powder $(<250$ $\mu \mathrm{m})$ as shown in Fig. 3(b) and stored for the adsorption experiment.

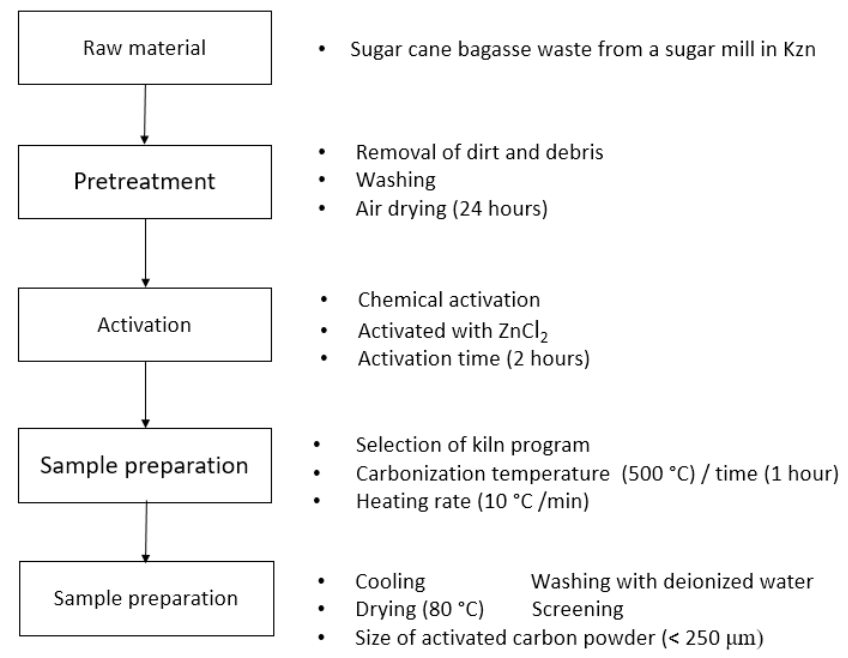

Fig. 2. Procedure for preparing Activated carbon
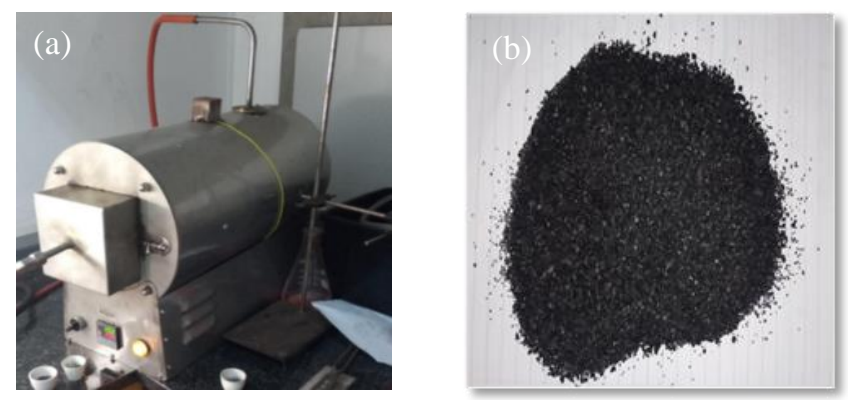

Fig. 3. (a) Horizontal kiln furnace (b) Activated carbon

\section{$2.3 \mathrm{CO}_{2}$ adsorption experiment}

The $\mathrm{CO}_{2}$ adsorption test was carried out using an adsorption column. For these experiments $99 \% \mathrm{CO}_{2}$ was used. In each 
experiment, the column was filled with $3.0 \mathrm{~g}$ of adsorbents (packing height $\approx 5.0 \mathrm{~cm}$ ) and placed within a temperature control bath to maintain a constant temperature at $30{ }^{\circ} \mathrm{C}$. The operating flow rate was varied from $(30-70) \mathrm{mL} / \mathrm{min}$ at constant temperature. The temperature of the thermostatic water bath was kept constant throughout the experiment. The experiment was allowed to operate for 1200 seconds (20 minutes) at each temperature $\left(30,50\right.$ and $\left.70{ }^{\circ} \mathrm{C}\right)$. The height of the bed was varied from $3-5 \mathrm{~cm}$ at each run to study the behaviour of the adsorbents. This experiment was controlled and recorded; the change in the mass of the sample was measured and the amount of $\mathrm{CO} 2$ adsorbed was calculated, by equation 3.3 below.

$\mathrm{CO}_{2}$ adsorption capacity $=\frac{\mathrm{W}_{2}-\mathrm{W}_{1}}{\mathrm{W1}} \times 1000$

Where $\mathrm{W}_{2}$ = weight of adsorbent after adsorption

$\mathrm{W}_{1}=$ weight of adsorbent before adsorption

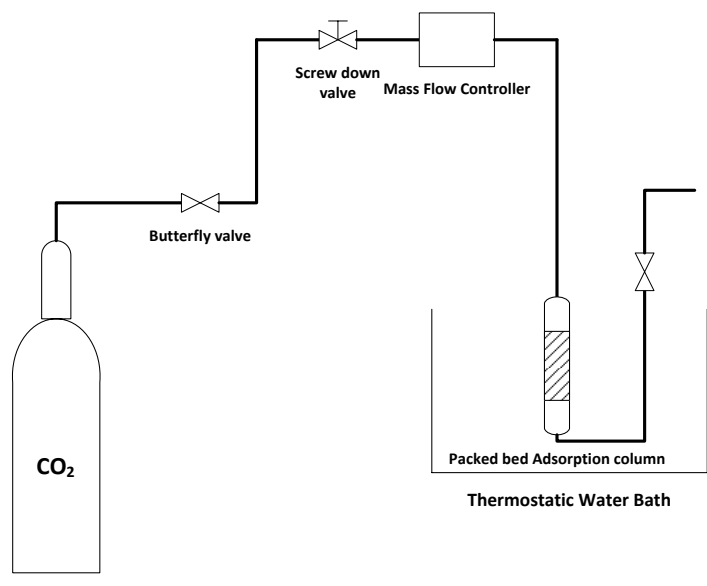

Fig. 4. Process flow diagram of the adsorption set-up

\section{RESULT AND DISCUSSIONS}

\subsection{SEM analysis}

Scanning electron microscopy (SEM) technique was employed to observe the surface physical morphology of the sugarcane bagasse derived activated carbon and kaolinite material. Figure 4 shows the SEM photographs of the sugarcane bagasse (before and after the carbonization at the optimum operating condition) and kaolinite material with $50000 \mathrm{X}$ magnification at a resolution of $2 \mu \mathrm{m}, 5 \mu \mathrm{m}$ and $20 \mu \mathrm{m}$. Pores of different size and shape could be observed. It can be seen from the micrographs Fig. (5b) that the external surface of the chemically activated carbon is full of caking and agglomeration occurring on the char structure and thus resulted in the formation of chars with an intact external surface. According to the micrograph, it seems that the higher aggregates resulted from the evaporation of $\mathrm{ZnCl}_{2}$ during carbonization, leaving the space previously occupied by the $\mathrm{ZnCl}_{2}$.

Interestingly, with the activation of the sugarcane bagasse with $\mathrm{ZnCl} 2$, the carbon structure of the sample increases and begins to cohere and form sphere-shaped porous variable-size structures. Such structures can help facilitate the movement of $\mathrm{CO}_{2}$ gas molecules by providing abundant sites for adsorption. This demonstrates that activation removes hydrocarbons, which enhances the adsorption capacity of activated carbon. Discrete aggregation was shown in Fig. (5c) and was characterized by the presence of a few mesopores and made spherical, making the surface rough.

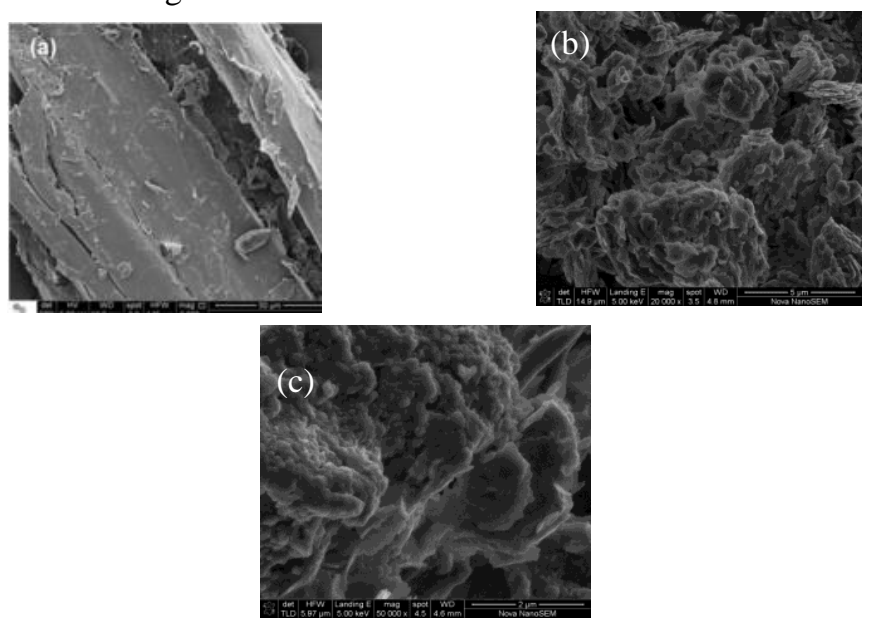

Fig. 5. Scanning electron microscopy images of sugarcane bagasse (a) before carbonization (b) after carbonization at $500{ }^{\circ} \mathrm{C}$ (c) kaolinite

\subsection{BET surface area}

BET surface area for sugarcane based activated carbon and kaolinite are shown in Table I. The BET surface area obtained was significantly high and it is within the acceptable range of commercial activated carbon $\left(500-1500 \mathrm{~m}^{2} / \mathrm{g}\right)$. Generally, with high BET surface area, results in higher adsorption capacity because the activated carbon is capable to adsorb a number of gases under different conditions [10].

We observed that for the chemical activated sample of sugarcane bagasse, SBAC provided a larger surface area, 979 $\mathrm{m}^{2} / \mathrm{g}$ compared to kaolinite, $584 \mathrm{~m}^{2} / \mathrm{g}$. This is because $\mathrm{ZnCl}_{2}$ as the activating agent has contributed to create more new pores and widen the existing pores. The chemical activated SBW also exhibited the highest pore volume $\left(0.43 \mathrm{~cm}^{3} / \mathrm{g}\right)$, followed by kaolinite $\left(0.26 \mathrm{~cm}^{3} / \mathrm{g}\right)$ which indicated higher gas adsorption. At this moment, adsorption of $\mathrm{CO}_{2}$ was not only related to BET surface area and pore volume, but also depended on reaction occurred between adsorbate $\left(\mathrm{CO}_{2}\right)$ and adsorbent (loaded $\mathrm{AC}$ ) and kaolinite samples.

TABLE I. BET SURFACE AREA

\begin{tabular}{llll}
\hline \hline & BET & Total pore & Average \\
Sample & $\begin{array}{l}\text { surface area } \\
\left(\mathrm{m}^{2} / \mathrm{g}\right)\end{array}$ & $\begin{array}{l}\text { volume } \\
\left(\mathrm{cm}^{3} / \mathrm{g}\right)\end{array}$ & $\begin{array}{l}\text { pore } \\
\text { diameter } \\
(\AA)\end{array}$ \\
\hline
\end{tabular}




\begin{tabular}{lccc}
\hline $\begin{array}{l}\text { Chemical } \\
\text { activated carbon } \\
\text { from SBW }\end{array}$ & 712 & 0.43 & 18.77 \\
Kaolinite & 484 & 0.26 & 14.09 \\
\hline
\end{tabular}

\subsection{FTIR analysis}

The FT-IR test results of sugar cane based activated carbon before and after $\mathrm{CO}_{2}$ adsorption are presented in Fig. 6 whereas the FT-IR test results of kaolinite before and after the adsorption of $\mathrm{CO}_{2}$ are depicted in Fig. 7. The functional group analysis was conducted at a range of $500-4000 \mathrm{~cm}^{-1}$ wavelengths.

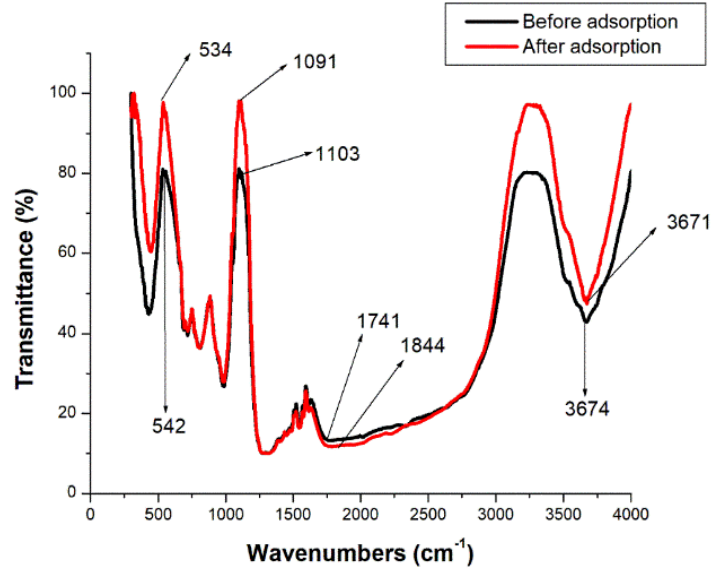

Fig. 6. The FTIR spectrum of sugar cane based activated carbon before and after adsorption

TABLE II: FTIR SPECTRAL CHARACTERISTICS OF ACTIVATED CARBON DERIVED FROM SUGAR CANE BEFORE AND AFTER ADSORPTION

\begin{tabular}{lll}
\hline \hline $\begin{array}{l}\text { Activated carbon } \\
\text { before adsorption }\end{array}$ & $\begin{array}{l}\text { Activated } \\
\text { carbon after } \\
\text { adsorption }\end{array}$ & $\begin{array}{l}\text { Assignment } \\
\text { s }\end{array}$ \\
\hline 3674 & 3671 & $\begin{array}{l}\text { OH-stretch } \\
\text { (in alcohol) }\end{array}$ \\
542 & 537 & $\begin{array}{l}\text { C-H } \\
\text { bending } \\
\text { C-O stretch } \\
\text { (in aliphatic } \\
\text { ether) } \\
\text { C-O stretch } \\
\text { (in } \\
\text { anhydride) }\end{array}$ \\
1103 & 1091 & 1844 \\
1741 & & \\
\hline
\end{tabular}

The variations in the FTIR spectrum of activated carbon derived from sugar cane bagasse can be shown in figure 4.2 before and after $\mathrm{CO}_{2}$ adsorption. A description of the features of the shifted bands and the existing functional groups is presented in Table II. As seen in Fig. 6, the activated carbon derived from sugar cane bagasse spectrum displaced an absorption peak of $3671 \mathrm{~cm}^{-1}$ clearly indicating the presence of an $\mathrm{O}-\mathrm{H}$ functional group. First, the broad peak at $3671 \mathrm{~cm}^{-1}$ shifted and became weak at $3641 \mathrm{~cm}^{-1}$ due to the $\mathrm{O}-\mathrm{H}$ stretch and the $\mathrm{H}$-bonding of the hydroxyl group in alcohols and phenols. The asymmetry of this band indicates the presence of strong hydrogen bonds.

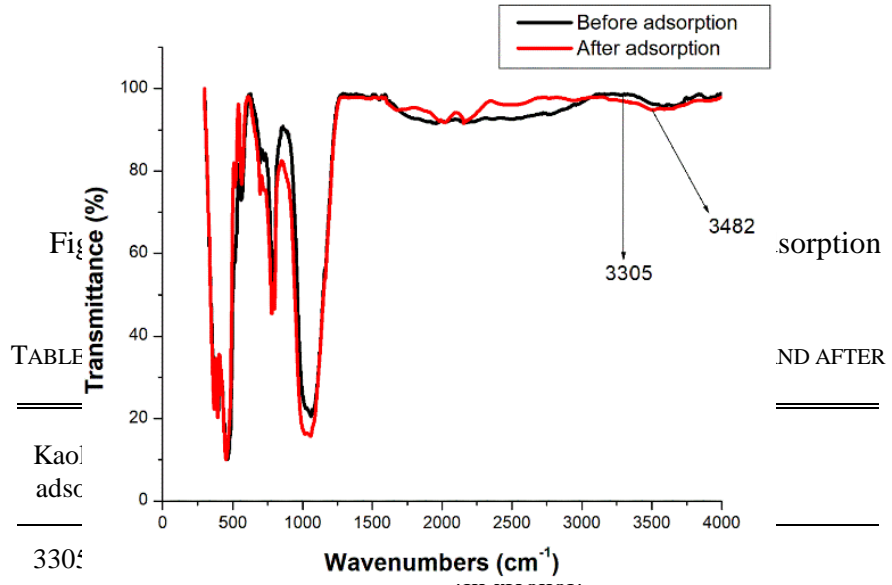

The peak $537 \mathrm{~cm}^{-1}$ which shifted to $542 \mathrm{~cm}^{-1}$ indicates the presence of C-H group. A strong band at $1844 \mathrm{~cm}^{-1}$ shifted to $1741 \mathrm{~cm}^{-1}$, attributed to the $\mathrm{C}=\mathrm{O}$ groups of anhydride compounds. Whereas for the kaolinite spectrum before and after adsorption of $\mathrm{CO}_{2}$ in Fig. 7, there is an absorption peak of $3305 \mathrm{~cm}^{-1}$ shifted to $3482 \mathrm{~cm}^{-1}$ confirming the formation of $\mathrm{O}-\mathrm{H}$ group that may incorporate water, alcohol, and phenol components. The comparison of the sugar cane derived activated carbon FTIR spectra before and after $\mathrm{CO}_{2}$ adsorption indicates the change in the spectrum that occurred and it can be said that the adsorbent's functional groups were actively engaged in the adsorption process [11]. Overall, it can be concluded that the sugar cane bagasse derived activated carbon has functional groups that can help bind or trap particles including alcohols, phenols, alkanes, and alkyl halides. The hydroxyl group has a strong affinity to pollutants and heavy metal ions [12].

\section{$3.4 \mathrm{CO}_{2}$ adsorption}

\subsubsection{Effect of temperature}

Fig. 8 (a) exhibits behaviour showing the effect of 
temperature on the $\mathrm{CO}_{2}$ adsorption capacity for SBAC and kaolinite. The effect of temperature was studied from 30 to 70

${ }^{0} \mathrm{C}$. It is expected that the temperature will influence the nature of the adsorption that occurs, i.e., physisorption or chemisorption. In other words, an increase in adsorption temperature results in a reduction in the amount of $\mathrm{CO}_{2}$ absorbed. Increased temperature gives more internal energy to $\mathrm{CO}_{2}$ molecules during the gas phase. We observed that the increased energy allows the diffusion of gaseous molecules at a higher rate. However, at the same time, the possibility of $\mathrm{CO} 2$ being constrained or trapped on the adsorbent surface by fixed energy adsorption sites is decreased. The highest adsorption capacity was obtained at $30^{\circ} \mathrm{C}$ for SBAC and kaolinite systems at $28.97 \mathrm{mgCO}_{2} / \mathrm{kg} \mathrm{AC}$ and $12.98 \mathrm{mgCO}_{2} / \mathrm{kg}$ kaolinite, respectively. The observed trend is that $\mathrm{CO}_{2}$ adsorption decreased with an increase in temperature. At a constant flowrate, the kinetic energy of gases increases with temperature, resulting in lesser surface coverage of $\mathrm{CO}_{2}$ gas. The observed trend can be attributed to the exothermic nature of the adsorption process. Le Chatelier's principle explains this, when it is applied to predict the extent of an exothermic process states that increasing the temperature will decrease the magnitude of an exothermic reaction

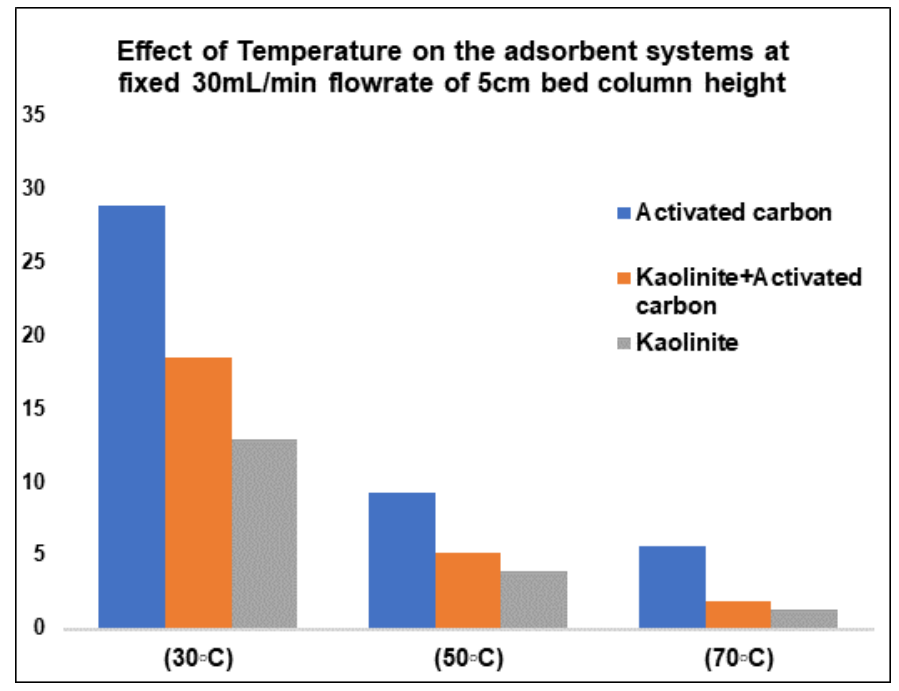

Fig. 8. Effect of temperature on $\mathrm{CO}_{2}$ adsorption capacity of kaolinite activated carbon

\subsubsection{Effect of flowrate}

Fig. 9 depicts the effect of flowrate on $\mathrm{CO}_{2}$ adsorption capacity of SBAC and kaolinite systems. The highest $\mathrm{CO}_{2}$ adsorbed was achieved using a flowrate of $30 \mathrm{~mL} / \mathrm{min}$. The $\mathrm{CO}_{2}$ adsorbed with a flowrate of $40 \mathrm{~mL} / \mathrm{min}, 50 \mathrm{~mL} / \mathrm{min}, 60 \mathrm{~mL} / \mathrm{min}$, and $70 \mathrm{~mL} / \mathrm{min}$ are lower than that achieved with a flowrate of $30 \mathrm{~mL} / \mathrm{min}$. We observed that decreasing the inlet flow rate of the gas increases the contact time and improves mass transfer between $\mathrm{CO}_{2}$ and the adsorbents. That is, lower flow rates increase the retention time of the $\mathrm{CO}_{2}$ molecules on the selected adsorbents within the packed bed adsorption column resulting in the high amount of $\mathrm{CO}_{2}$ adsorbed. At lower flow rate, adsorbate $\left(\mathrm{CO}_{2}\right)$ has more time to contact with adsorbent that resulted in higher adsorption capacity of $\mathrm{CO}_{2}$ [13]. Longer residence times are required for a higher amount of $\mathrm{CO}_{2}$ to be adsorbed and entrapped in the pores of the adsorbents. As a result of the aforementioned reasons, the maximum amount of $\mathrm{CO}_{2}$ adsorbed at constant temperature of $30^{\circ} \mathrm{C}$ by sugarcane based activated carbon and kaolinite systems at different flow rates of $30 \mathrm{~mL} / \mathrm{min}, 40 \mathrm{~mL} / \mathrm{min}, 50 \mathrm{~mL} / \mathrm{min}, 60 \mathrm{~mL} / \mathrm{min}$ and 70 $\mathrm{mL} / \mathrm{min} \mathrm{CO}_{2}$ were $20.45,19.62,16.82,14.70$ and 12.11 $\mathrm{mgCO}_{2} / \mathrm{kg}$ adsorbent as depicted in Fig. 9.

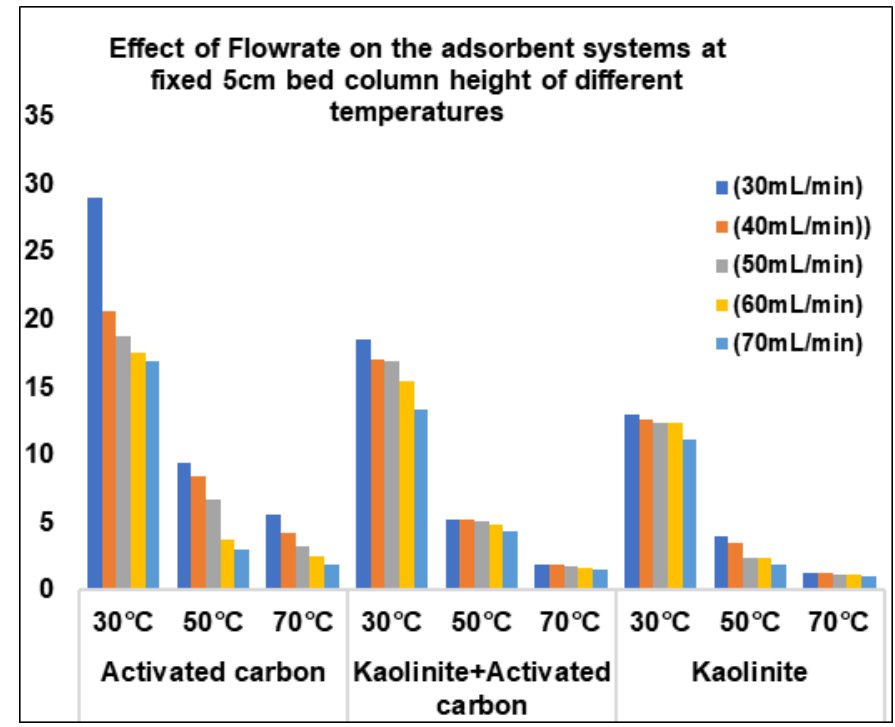

Fig. 9. Effect of flowrate on $\mathrm{CO}_{2}$ adsorption capacity of activated carbon. Constant temperature of $70^{\circ} \mathrm{C}$

\subsubsection{Effect of column height}

The adsorption capacity of the packed bed increased with increasing bed height; the determined heights of bed were 3, 4 and $5 \mathrm{~cm}$ to examine the effect on the $\mathrm{CO}_{2}$ adsorption performance of sugarcane based activated carbon and kaolinite systems. The flow rate was kept constant at about $30 \mathrm{~mL} / \mathrm{min}$ to $70 \mathrm{~mL} / \mathrm{min}$. The effect of bed height for $\mathrm{CO}_{2}$ adsorption onto SBAC and kaolinite samples at heights of 3,4 , and $5 \mathrm{~cm}$ is shown in Fig. 10, which indicated that $\mathrm{CO}_{2}$ adsorption capacity for the bed heights of 3-5 cm were increasing. The highest adsorption capacity of $\mathrm{CO}_{2}$ for SBAC and kaolinite systems was achieved at the height of $5 \mathrm{~cm}$. The good performance of $\mathrm{CO}_{2}$ adsorption on sugar cane based activated carbon at a bed height of $5.0 \mathrm{~cm}$ could also be attributed to more contact opportunities between the $\mathrm{CO}_{2}$ gas and adsorbent particles. However, the mass transfer zone broadened since an increase in bed height causes greater resistance to mass transfer and slower kinetics of adsorption [14]. This was attributed to an increase in the surface area and the number of binding sites available for adsorption. The time for interaction of adsorbate and adsorbent also increased with an increasing amount of adsorbent $[15,16]$ 


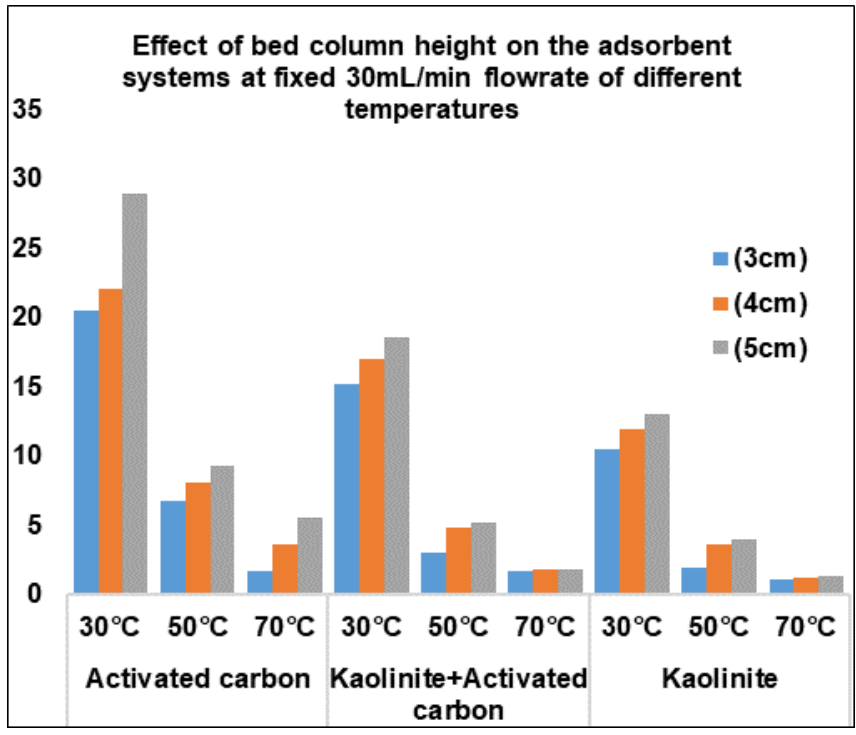

Fig. 10. Effect of height on $\mathrm{CO}_{2}$ adsorption capacity of activated carbon. Constant temperature of $30^{\circ} \mathrm{C}$

\section{CONCLUSIONS}

This study has demonstrated that reasonably good surface area activated carbons can be prepared from the chemical activation of sugarcane bagasse waste with $\mathrm{ZnCl}_{2}$ as activating agent. For the carbonization of the $\mathrm{ZnCl}_{2}$ treated sample, the release of moisture and $\mathrm{ZnCl}_{2}$ represents most of the evolution, indicating that $\mathrm{ZnCl}_{2}$ plays an important role in increasing the surface area during carbonization. However, kaolinite, a cheap and commonly available clay mineral can also be utilized for $\mathrm{CO}_{2}$ capture as it acts as a pollutant collector. Study of various parameters during $\mathrm{CO}_{2}$ capture via adsorption revealed that temperature, flowrate, and column height influences the amount of $\mathrm{CO}_{2}$ adsorbed. Under the experimental conditions investigated, the best conditions for the production of high surface area activated carbon from sugarcane bagasse waste by chemical activation are: chemical ratio (activating agent/precursor) of $100 \%$, carbonization time of $1 \mathrm{~h}$ and carbonization temperature of $500{ }^{0} \mathrm{C}$. At this optimal condition, the BET surface area obtained were $712 \mathrm{~m}^{2} / \mathrm{g}$ and $484 \mathrm{~m}^{2} / \mathrm{g}$ for sugarcane based activated carbon (SBAC) and kaolinite samples, respectively. The properties of SBAC and kaolinite samples were characterized in terms of FT-IR, BET surface area and SEM. FT-IR results indicated all the adsorbent's functional groups that were actively engaged in the adsorption process. According to BET, SBAC exhibited the highest pore volume $\left(0.43 \mathrm{~cm}^{3} / \mathrm{g}\right)$, followed by kaolinite $(0.26$ $\mathrm{cm}^{3} / \mathrm{g}$ ) which indicated higher gas adsorption. At higher temperature, the $\mathrm{CO}_{2}$ adsorption capacity for each adsorbent was reduced. It appears that the sugarcane based activated carbon (SBAC) have stronger adsorption sites compare to the kaolinite samples [17]. Based on these findings, it can be concluded that the use of activated carbon derived from sugar cane bagasse and kaolinite is a promising alternative for $\mathrm{CO}_{2}$ capture.

\section{ACKNOWLEDGMENT}

The authors gratefully acknowledge the help received from Mrs. J. N. Thiloshini and Mr. R. K. Dwari of DUT Research Laboratory, Durban, South Africa for porosity analysis of samples.

\section{REFERENCES}

[1]Sumathi, S., et al., Optimization of microporous palm shell activated carbon production for flue gas desulphurization: Experimental and statistical studies. Bioresource technology, 2009. 100(4): p. 1614-1621. https://doi.org/10.1016/j.biortech.2008.09.020

[2] Arami-Niya, A., et al., Production of microporous palm shell based activated carbon for methane adsorption: modeling and optimization using response surface methodology. Chemical engineering research and design, 2012. 90(6): p. 776-784. https://doi.org/10.1016/j.cherd.2011.10.001

[3] Xie, J., et al., CO 2 adsorption performance of ZIF-7 and its endurance in flue gas components. Frontiers of Environmental Science \& Engineering, 2014. 8(2): p. 162-168. https://doi.org/10.1007/s11783-013-0507-2

[4] Viswanathan, B., P.I. Neel, and T. Varadarajan, Methods of activation and specific applications of carbon materials. India, Chennai, 2009.

[5] Bachrun, S., et al. Preparation and characterization of activated carbon from sugarcane bagasse by physical activation with CO2 gas. in IOP Conf. Ser. Mater. Sci. Eng. 2016.

https://doi.org/10.1088/1757-899X/105/1/012027

[6] Budi, E., et al., Adsorption and Pore of Physical-Chemical Activated Coconut Shell Charcoal Carbon. MS\&E, 2018. 335(1): p. 012007. https://doi.org/10.1088/1757-899X/335/1/012007

[7] Matali, S., et al. Removal of selected gaseous effluent using activated carbon derived from oil palm waste: An Overview. in IEEE Symposium on Business, Engineering, and Industrial Applications. 2013.

[8] Ioannidou, O. and A. Zabaniotou, Agricultural residues as precursors for activated carbon production - a review. Renewable and sustainable energy reviews, 2007. 11(9): p. 1966-2005. https://doi.org/10.1016/j.rser.2006.03.013

[9] Allwar, A. Characteristics of micro-and mesoporous structure and surface chemistry of activated carbons produced by oil palm shell. in International Conference on Chemical, Ecology and Environmental Sciences Proceedings. 2012.

[10] Skodras, G., et al., Enhanced mercury adsorption in activated carbons from biomass materials and waste tires. Fuel processing technology, 2007. 88(8): p. 749-758. https://doi.org/10.1016/j.fuproc.2007.03.008

[11] Chang, K.-L., et al., Adsorption studies on the removal of an endocrine-disrupting compound (Bisphenol A) using activated carbon from rice straw agricultural waste. Separation Science and Technology, 2012. 47(10): p. 1514-1521. https://doi.org/10.1080/01496395.2011.647212

[12] Lazim, Z.M., et al., The removal of methylene blue and Remazol Brilliant $B l u e ~ R$ dyes by using orange peel and spent tea leaves. Jurnal Teknologi, 2015. 74(11). https://doi.org/10.11113/jt.v74.4882

[13] Ahmad, A. and B. Hameed, Fixed-bed adsorption of reactive azo dye onto granular activated carbon prepared from waste. Journal of hazardous materials, 2010. 175(1-3): p. 298-303. https://doi.org/10.1016/j.jhazmat.2009.10.003

[14] Nouri, H. and A. Ouederni, Modeling of the dynamics adsorption of phenol from an aqueous solution on activated carbon produced from olive stones. International Journal of Chemical Engineering and Applications, 2013. 4(4): p. 254. https://doi.org/10.7763/IJCEA.2013.V4.306

[15] Fat'hi, M.R., et al., Kinetics and thermodynamic studies for removal of acid blue 129 from aqueous solution by almond shell. Journal of Environmental Health Science and Engineering, 2014. 12(1): p. 62. https://doi.org/10.1186/2052-336X-12-62

[16] Teutscherova, N., et al., Leaching of ammonium and nitrate from Acrisol and Calcisol amended with holm oak biochar: A column study. Geoderma, 2018. 323: p. 136-145.

https://doi.org/10.1016/j.geoderma.2018.03.004 
[17] Pellerano, M., et al., CO2 capture by adsorption on activated carbons using pressure modulation. 2009. 1(1): p. 647-653.

https://doi.org/10.1016/j.egypro.2009.01.085

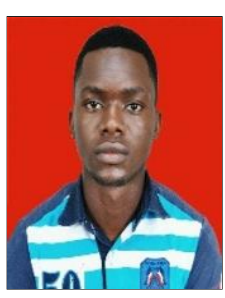

S.O Akpasi is currently a master student of the Department of Chemical Engineering at Durban University of Technology, Steve Biko Campus, Durban, South Africa. He was born on January 17, 1992 in Kano, Nigeria. He obtained his Bachelor of Engineering degree (2014) from the Department of Chemical Engineering in Delta State University, Abraka, Nigeria. His research focuses on climate change (environmental management).

Aside from being a researcher, he is also a tutor in Durban University of Technology. He has helped many students to develop and understand the concept of chemical engineering fundamentals. He is currently writing a dissertation paper about the "evaluation of kaolinite and activated carbon performance for $\mathrm{CO}_{2}$ capture".

Mr. S.O Akpasi has received professional certifications on oil and gas management, project management, and facility management $\&$ operations. 